\title{
Finding alternatives to swidden agriculture: does agroforestry improve livelihood options and reduce pressure on existing forest?
}

\author{
Syed Ajijur Rahman · Jette Bredahl Jacobsen • \\ John Robert Healey • James M. Roshetko • \\ Terry Sunderland
}

Received: 2 March 2015/ Accepted: 22 February 2016/Published online: 8 March 2016

(C) The Author(s) 2016. This article is published with open access at Springerlink.com

\begin{abstract}
Swidden cultivation can contribute to deforestation and land degradation, which can subsequently result in a number of serious environmental problems. This paper examines the economic and social potential of agroforestry systems and the barriers to their widespread adoption, as a land use alternative to swidden cultivation, which may potentially help protect local forest. The Gunung Salak valley in West Java, Indonesia is presented as a case study. Based on farmers' and experts' assessment, costs and benefits have been estimated, which show that the two investigated agroforestry systems have
\end{abstract}

\section{S. A. Rahman $(\bowtie) \cdot$ J. B. Jacobsen}

Department of Food and Resource Economics, Section of Environment and Natural Resources, University of Copenhagen, 1958 Frederiksberg, Denmark

e-mail: sumonsociology@yahoo.com

S. A. Rahman · J. R. Healey

School of Environment, Natural Resources and

Geography, Bangor University, Bangor LL57 2UW, UK

S. A. Rahman · T. Sunderland

Center for International Forestry Research (CIFOR),

Bogor Barat 16115, Indonesia

J. B. Jacobsen

Center for Macroecology, Evolution and Climate, University of Copenhagen, Universitetsparken 15,

Building 3, 2100 Copenhagen, Denmark

J. M. Roshetko

World Agroforestry Centre (ICRAF), Bogor Barat 16115, Indonesia higher net present value and benefit-cost ratio $(\mathrm{B} / \mathrm{C})$ than the two swidden cultivation systems. Tree ownership also creates more permanent rights to farmland and is prestigious in the community. Agroforestry products (fruit, vegetables etc.) have high monetary value and help strengthen social cohesion when shared with neighbors. However, farmers are reluctant to implement agroforestry. Stated reasons are related to both culture and capacity. Farmers practicing agroforestry are less involved in forest clearing and forest products collection than swidden farmers indicating that it may contribute positively to conservation of local forests. Increasing the adoption of agroforestry farming in the study area will require support to overcome capacity constraints.

Keywords Agroforestry adoption · Income $\cdot$ Social potential $\cdot$ Forest protection $\cdot$ Policy support

\section{Introduction}

Swidden agriculture, also known as slash-and-burn farming is a widespread subsistence practice in the tropics (Peng et al. 2014; Schuck et al. 2002). Swidden is mainly practiced in the mountainous and hilly parts of Latin America, Central Africa and Southeast Asia by smallholder farmers (Munthali 2013; Van et al. 2012), and often drives deforestation as well as forest degradation (Rahman et al. 2012; Styger et al. 2006). 
Multiple terms are used to refer to swidden cultivation and related systems in the scientific literature: swidden agriculture, shifting cultivation, slash-and-burn farming, as well as regional terms jhum in South Asia or ladang in Indonesia (Van et al. 2012; Mertz et al. 2009; Imang et al. 2008). 'Swidden' was first proposed as a term by the Swedish anthropologist K.G. Izikovitz in 1951 in the sense of burning woody vegetation to clear land for agriculture (Peng et al. 2014; Russell 1988). 'Shifting cultivation' is often used more broadly to refer to agricultural activities where fields are cultivated for crop production for a number of years and then left fallow for a number of years (Vongvisouk et al. 2014; Therik 1999). However, others define it more narrowly to refer to systems in which the entire livelihoods of farmers are shifted with the cultivation within the forest landscape (Aweto 2013; Inoue 2000; Adimihardja 1992). Our focus is on swidden that does not necessarily refer to shifting fields but only to land cleared by burning (Peng et al. 2014; Marten 1986), as is the case in our research site in Gunung Salak.

In Gunung Salak valley, West Java, Indonesia swidden cultivation practices are deeply rooted in communities' culture and provide various subsistence products mostly to local poor farmers (Galudra et al. 2008). However, this system can have serious negative environmental consequences by contributing to deforestation and land degradation (Peng et al. 2014; Rahman et al. 2012; Barraclough and Ghimire 1995; Gupta 1993). The most severe environmental impacts occur in two ways, firstly, when the swidden cultivators clear forests to prepare land for cultivation and, secondly, from the forest clearing process fire can escape and burn uncontrolled in adjacent forest areas (Rahman et al. 2012; Mai 1999). Loss of forest cover and degradation of remaining forest can greatly increase the incidence of soil erosion in areas on steep slopes (Shoaib et al. 1998; Sfeir-Younis and Dragun 1993). Soil erosion and landslides have negative effects on a range of ecosystem services including food provisioning from agriculture in both uplands and lowlands, and can negatively affect farm families' standards of living (Rahman et al. 2012).

In order to overcome the negative consequences of swidden, farmers would need to adopt new practices that serve multiple purposes including conserving forest resources as well as producing food and supporting sustainable development (Leakey 2010;
Roshetko et al. 2008; Sunderland et al. 1999). Agroforestry, and specifically the practice of growing trees on farmland alongside crops, has well-established research evidence of its potential to reduce deforestation and forest degradation at a landscape scale (Rahman et al. 2014; Idol et al. 2011; Garrity 2004). One definition of agroforestry is 'a dynamic, ecologically-based, natural resources management system that, through the integration of trees on farms and in the agricultural landscape, diversifies and sustains production for increased social, economic and environmental benefits for land users at all levels' (Mead 2004). In response to both environmental concerns and the need to ensure the sustenance of livelihoods, there are many examples where agroforestry is advocated as a potential solution to the need to develop a more sustainable form of land use that improves farm productivity while, at same time, improving the welfare of the community (Roshetko et al. 2013; Leakey et al. 2012; Ahmed and Rahman 2000). Agroforestry can be more financially profitable to local farmers than traditional monoculture systems, and support the transition to permanent cultivation (Rahman et al. 2014; Franzel and Scherr 2002; Predo 2002; Mai 1999). Agroforestry is not only financially, but also environmentally, promising compared with simpler systems, by ameliorating the agroclimate and increasing biodiversity (Jessica et al. 2014; Swallow et al. 2006; Huxley 1993), protecting soil organic matter and increasing nutrient cycling (Elevitch and Wilkinson 1998; Wu 1996; SaeLee et al. 1992).

If agroforestry is really as beneficial as scientific studies suggest, the logical prediction would then be that this system would be adopted by a high proportion of farmers. However, this is not the case in large areas of the tropics (Meijer et al. 2015; Jepma 2013; Dahlquist et al. 2007; Kiptot et al. 2007; Craswell et al. 1998). The research reported in this paper addresses this issue by analyzing the value of existing agroforestry systems, investigating their economic and social potential relative to swidden farming. We also seek to identify what factors are barriers to widespread agroforestry adoption. This information would be valuable for the development of appropriate strategies to encourage more farmers to adopt agroforestry and to improve management of existing agroforestry systems (Fisher and Bunch 1996; Saxena and Ballabh 1995; Nair and Dagar 1991). We also 
assess the evidence that agroforestry may better conserve forest, by comparing forest products' extraction and land clearing between agroforestry and swidden farmers.

\section{Materials and methods}

Study site

The study area lies between $6^{\circ} 32^{\prime} 11.31^{\prime \prime} \mathrm{S}$ and $6^{\circ} 40^{\prime} 08.94^{\prime \prime} \mathrm{S}$ latitudes and between $106^{\circ} 46^{\prime} 12.04^{\prime \prime} \mathrm{E}$ and $106^{\circ} 47^{\prime} 27.42^{\prime \prime} \mathrm{E}$ longitudes, and is located in the Gunung Salak valley, Bogor District, west Java, Indonesia. The reason for selecting this site is that both agroforestry and swidden cultivation are practiced by farmers in the same communities and environments. Thus their economic and social potential can be compared and the barriers to agroforestry adoption can be investigated with precision. The sustainability of livelihoods in the study area, like much of Indonesia, is threatened by overall poverty with low income and poor infrastructure development (Badan Pusat Statistik 2013), and the expansion of subsistence agriculture (especially swidden) due to rapid population growth is a major contributing factor to forest loss and environmental degradation (EST 2015; Galudra et al. 2008). Moreover, restrictions on the harvest of some products (e.g. timber) from natural forest provide an economic incentive for smallholders to integrate trees into their farming systems. All of these characteristics of the study area are representative of a large proportion of Indonesian and tropical Asian agricultural landscapes.

The climate in this region is equatorial with two distinct seasons, ${ }^{1}$ i.e. dry (April-October) and rainy (November-March). The region is more humid and rainy than most parts of west Java, the average relative humidity and annual precipitation are $70 \%$ and $1700 \mathrm{~mm}$ respectively. The average temperature is $25.9{ }^{\circ} \mathrm{C}$, and the diurnal range is $9-10{ }^{\circ} \mathrm{C}$, rather high for Indonesia (Badan Pusat Statistik 2013; Wiharto et al. 2008). The soils are highly fertile and dominated by volcanic sedimentary rocks. Given the proximity of large active volcanoes, the area is considered highly seismic.

\footnotetext{
${ }^{1}$ In the study site rainfall occurs throughout the year, but based on its intensity, two seasons are recognised, where heavy rainfall occurs in the "rainy" season.
}

Field data were collected during January-August, 2013 from two purposively selected ${ }^{2}$ sample villages, i.e. Sukaluyu and Tamansari located in the northern valley of Gunung Salak, where the total population is approximately 8200 , living in 1200 households. The study site has poor infrastructural facilities, and the local economy is mainly based on agricultural and forest products (Badan Pusat Statistik 2013). Our survey showed that in the two villages most community members have small land holdings $(<1$ ha) and carry out subsistence agriculture. Upland rice, irrigated rice, maize, and varieties of vegetables and fruits are the main agricultural crops. Land is used in various ways, such as rice fields (sawah), gardens (kebun), mixed gardens (kebun talun), mixed forests (talun) and swidden cultivation fields (huma/ladang) (Kleden et al. 2009). Private land use rights are granted by the government but farmers have no formal rights to state forest land. In the agroforestry farms, people cultivate various fruits, e.g. durian (Durio zibethinus), mango (Mangifera indica), rambutan (Nephelium lappaceum) and menteng (Baccaurea racemosa), and timber trees, e.g. teak (Tectona grandis), sengon (Albizia falcataria) and Jabon (Anthocephalus chinensis), with various understory crops, e.g. cassava (Manihot esculenta), maize (Zea mays), pineapple (Ananas comosus) and cincau (Cylea barbata). In the swidden fields, people commonly cultivate upland rice (Oryza javanica), maize (Zea mays), yam (Dioscorea spp.), beans (Dolichos lablab) and cassava (Manihot utilissima). Fruits, vegetables, bamboo, rattan and firewood are also collected from nearby forests. Agricultural and forest products are sold in the local and district markets, and are an important source of household income, besides wage labor, and retailing.

Data collection

Primary data were collected by rapid rural appraisal (RRA) for the basic socio-economic and geographical information of the research site using village mapping and key informant interviews (FAO 2015; Angelsen et al. 2011). These sessions were conducted by involving village heads in the purposive selection of

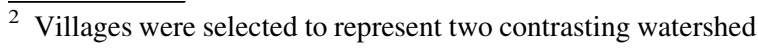
locations, i.e. mid-stream (Sukaluyu) and up-stream (Tamansari); and having the largest sample size of farm households, i.e. agroforestry and swidden.
} 
farmers based on their knowledge about the village and surrounding areas.

Two focus group discussion (FGD) sessions (one in each village ${ }^{3}$ ) and field observation methods were used to identify the types of local cultivation systems and their contribution to local livelihoods. The village heads and local farmer representative groups (consisting of eight to twelve farmers ${ }^{4}$ ) were present in the FGD sessions. Field observations were carried out in 25 locations which were decided based on the information gathered from RRA and FGD. During the observation period, several pictures of local cultivation systems were taken, and relevant information was noted with the help of an expert local informant. $^{5}$

In-depth interviews of farmers were conducted to obtain the data needed for cost-benefit analysis of agroforestry and swidden. Two agroforestry farms of contrasting types (i) durian and cassava (agroforestry 1) and (ii) teak, yam and maize (agroforestry 2); and two swidden farms of contrasting types (i) upland rice (swidden 1) and (ii) maize (swidden 2), were selected. Based on the output of FGDs and field observations, these four farm types were purposefully selected by the first author as being popular (commonly adopted at a wider range) and providing the highest incomes among the farm populations in the agroforestry and swidden farming categories. During the interviews, the farmers were asked several questions about the actual and envisaged costs and benefits of each cultivation system, i.e. establishment cost, total yields, total labor requirement, cost of irrigation, pesticides, and fertilizer. The data collected from the four cultivation systems were checked with a local government agriculture officer to verify that the absolute values were in the expected range based on his experience of farming systems in the study area.

\footnotetext{
$\overline{3}$ One semi-structured questionnaire interview (village survey, consisting of a set of questions concerning basic information about the village, e.g. demographic, infrastructure, land use) was also conducted during the FGD.

${ }^{4}$ Farmers in each group were purposively selected based on their knowledge of local cultivation systems.

5 One resident of the study site, who had considerable knowledge of local land use systems, products, markets and institutions, was employed as an expert local informant. This informant was present during the whole period of fieldwork, and helped check the validity of information obtained.
}

Twenty agroforestry and 20 swidden farmers were selected for semi-structured questionnaire interviews to collect information about their land holding area, income, farming benefits to their livelihood, forest products (FPs) collection, the area of forest that they cleared, ${ }^{6}$ and the barriers to agroforestry adoption that they faced. Due to the range of land use practices and the unequal distribution of farms in the study area, purposive sampling was used to select farms that adequately represented the full development of the system type into which they were classified within the range of local land use practices. ${ }^{7}$ We estimate that they represent about 30 and $40 \%$ of the farmer populations who are practicing agroforestry and swidden respectively. A number of questions were refined with the help of the expert local informant and during FGD sessions to make sure that they elicited the information required. The product value of crops was calculated with the key informant farmers during the interview based on the amount harvested in one production year (the most recent year).

Other data were gathered from the local government forestry office, the Southeast Asian regional office of ICRAF and CIFOR headquarters located in Bogor, west Java, to corroborate the primary data that were collected from the research site, and for background information and qualitative inputs for the study.

Analysis

Qualitative analysis was carried out using the narrative analysis technique, particularly to investigate the social potential of existing agroforestry systems. For cost benefit analysis, the net present value (NPV), benefit-cost ratio $(\mathrm{B} / \mathrm{C})$ and payback period were

\footnotetext{
${ }^{6}$ Households were asked whether or not in the last five years they had cleared any forest, and if yes, we also asked how much, and for what purpose it was cleared. We have used FAO's forest definition (FAO 2000), which defined forest as lands of more than 0.5 hectares, with a tree canopy cover of more than $10 \%$, where the trees should be able to reach a minimum height of $5 \mathrm{~m}$ in situ, and which are not primarily under agricultural land use.

${ }^{7}$ For example, some farmers started agroforestry farming but after a few years gave up planting the understory, for various reasons (e.g. lack of management interest or capital). Thus many agroforestry farms were converted to simple tree orchards, and we have excluded them from our sample. In fact very few farmers had developed the system type in full, and this was the only basis for the selection of farms who met that criterion.
} 
calculated and compared following Stocking et al. (1990). The NPV determines the present value of net benefits by discounting the streams of benefits and costs back to the beginning of the base year (Disney et al. 2013; Stocking et al. 1990). The NPV is calculated by the following formula:

$N P V=\sum_{t=0}^{T} \frac{\left(B_{t}-C_{t}\right)}{(1+r)^{t}}$

where $B_{t}$ is the benefits of production by a cultivation practice, $C_{t}$ is the costs of production by a cultivation practice, $t$ is the time, running until the end of the investment at $\mathrm{T}, r$ is the discount rate.

The B/C compares the discounted benefits with discounted costs. A B/C of greater than 1 means the cultivation is profitable, whilst a $\mathrm{B} / \mathrm{C}$ of less than 1 means that it generates losses. The $\mathrm{B} / \mathrm{C}$ is calculated as follows:

$\frac{B}{C}=\frac{\sum_{t=0}^{n} \frac{B}{(1+r)^{t}}}{\sum_{t=o}^{n} \frac{C_{t}}{(1+r)^{t}}}$

The payback period measures the number of years it will take for the undiscounted net benefits to repay the investment (Stocking et al. 1990).

\section{Assumptions}

\section{Land and establishment cost}

The market for agricultural land is underdeveloped in the study area, therefore the price of land is difficult to identify. However, as mentioned by Macdicken and Vergara (1990), there is no need to value the land separately if farmers want to change the use of their existing land to agroforestry. Thus, in our analysis the land value is omitted from the calculation. Establishment costs include: i) labor cost for land preparation, and ii) the price of seeds, seedlings and fertilizer which are required to start a project.
Yields

Crop components included in calculations for the selected cultivation systems are summarized in Table 1. The values of yields were calculated on an annual basis. Yields of durian (from grafted seedlings) are calculated under three categories, i) low yields during the fourth to sixth year, ii) medium yields during the seventh to eighth year, iii) high yields from the ninth year onwards. The market value of timber for the teak, yam and maize agroforestry system is calculated in ten-year rotation periods, after which it is assumed that teak is replanted.

\section{Labor}

Farmers often use family labor for farm work, but hired labor is also important in the study area. Family labor is not a cash expenditure from the farmer's perspective, and it is complicated to identify the amount of family labor contributed to each cultivation system, as farmers have different household size and labor availability. Therefore, all calculations were conducted based on the total amount of labor $^{- \text {day }}$ required for each cultivation system.

\section{Pesticides, fertilizer, irrigation}

Even though pesticides and fertilizers are minimally used in swidden and for understory crops in agroforestry, the costs are calculated based on the amount used in one production year as reported during the interviews. The cost of irrigation is ignored as high intensity rainfall occurs throughout the year, thus irrigation is not a cash expenditure for farmers.

Time horizon for analysis

Once forest trees are included in the agroforestry system the lifespan of this project can be considered indefinite. However, for simplicity, in our analysis the project life
Table 1 Brief description of selected cultivation systems for analysis

\begin{tabular}{lll}
\hline Cultivation system & Component & Cultivation type \\
\hline Agroforestry 1 & Durian, cassava & Permanent \\
Agroforestry 2 & Teak, yam, maize & Rotational @ 10 year \\
Swidden 1 & Upland rice & Semi-permanent \\
Swidden 2 & Maize & Semi-permanent \\
\hline
\end{tabular}




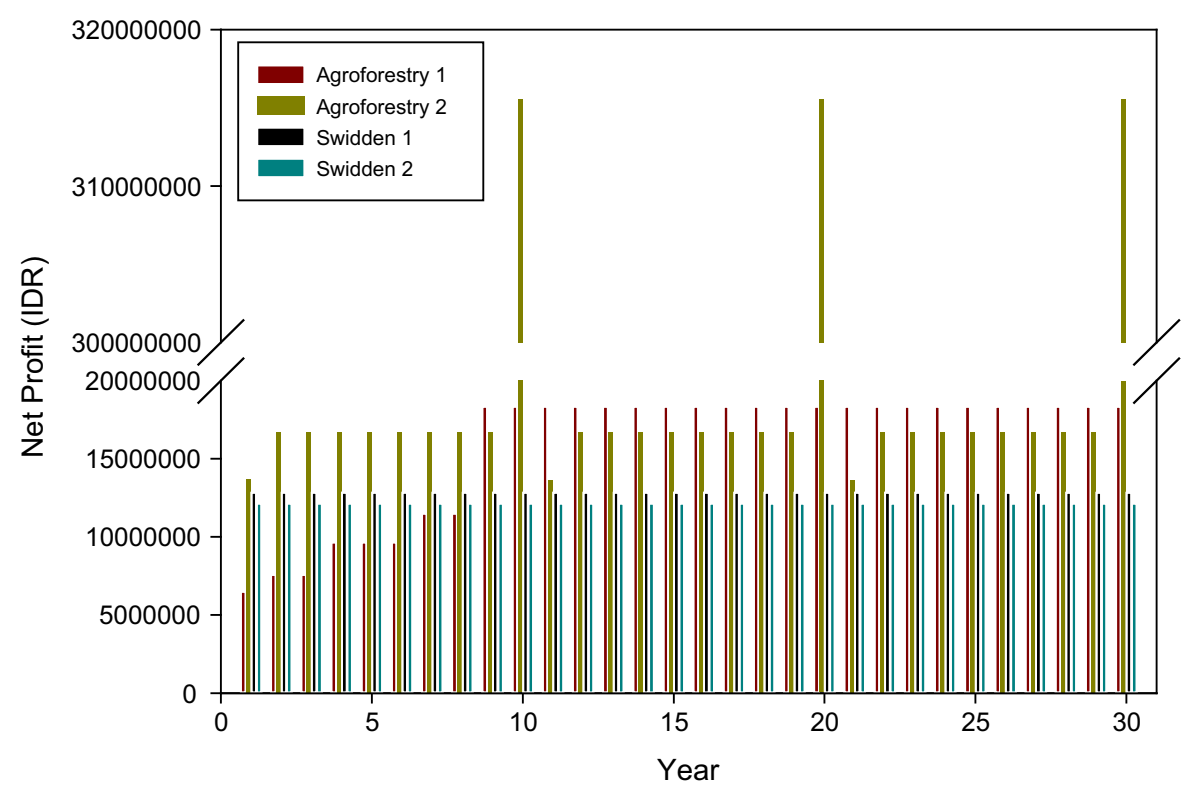

Fig. 1 Annual cash flow (net profit) of different cultivation systems (IDR/ha)

is considered to be 30 years as this may be a realistic lifetime for one rotation of durian trees in agroforestry system 1, which has the longest cycle. The consequence is that trees planted for timber in agroforestry system 2 can have three rotations (harvest cycles) and other crops have 30 annual cultivation cycles during the project lifespan. A similar time horizon is used in other comparable studies (e.g. Rahman et al. 2008, 2014).

\section{Results}

The cash flow of the four different cultivation systems (Fig. 1), and the calculations of NPV and especially $\mathrm{B} / \mathrm{C}$, show that both agroforestry systems are more profitable than the two swidden systems (Table 2). Whereas profitability measured by NPV is similar in three of the systems, for agroforestry system 2 (with teak) it is almost three times higher. This is driven by the high output prices of the teak timber production from this system. Even though teak-based agroforestry requires some additional costs during rotations, these are offset by the return from selling timber. Furthermore, the value of intensively managed diversified understory crop yields in the teak-based system is higher than for both swidden systems, thus agroforestry system 2 is the superior land use option in the study site.
Risk factors should be accounted for in the financial analysis, as agricultural projects may face a wide variety of risks. ${ }^{8}$ Furthermore, it is important to consider the assumptions in the calculations. Therefore, sensitivity analysis was conducted on changes in discount rate $^{9}$ (Table 3), and variation in yields (Table 4). Regardless of the discount rate used, agroforestry 2 remains the most profitable system, whereas agroforestry 1 provides a lower NPV than the two swidden systems for discount rates of $20 \%$ and above. In the case of decrease in yields, the NPV of both agroforestry systems are always positive and higher than swidden cultivation (Table 4).

No difference in payback period was found between the four systems (Table 2). A 1 year payback period for the agroforestry systems indicates that within a year the undiscounted net benefit is high enough to repay the comparatively higher investment in establishing this system.

\footnotetext{
$\overline{8}$ Many natural risk factors are site specific (e.g. landslides, lava flows) whereas others are more widespread (e.g. storms). Some threats are induced by humans, such as fire, pest introductions and price fluctuation (e.g. if supply is increased due to increases in output due to expansion of farm production).

9 One method to include risk into analysis is to use an increased discount rate, which reflects the added yearly risk of a project (see Elevitch and Wilkinson 2000).
} 
Table 2 Annual cost and revenue of selected cultivation systems in Indonesian Rupiah (IDR) per hectare

\begin{tabular}{|c|c|c|c|c|c|}
\hline Type of operation & Year & Agroforestry 1 & Agroforestry 2 & Swidden 1 & Swidden 2 \\
\hline Site preparation & 0 & 375,000 & 500,000 & 180,000 & 180,000 \\
\hline \multirow{11}{*}{$\begin{array}{l}\text { Operational cost, i.e. labor, seeds, seedlings, } \\
\text { fertilizer, pesticide }\end{array}$} & 1 & 2161,667 & 5130,150 & & \\
\hline & $2-3$ & 1461,667 & & & \\
\hline & $4-6$ & $1581,667 *$ & & & \\
\hline & $7-8$ & $1641,667 *$ & & & \\
\hline & $9-30$ & $1701,667 *$ & & & \\
\hline & $\ldots \ldots \ldots$ & & & & \\
\hline & $\begin{array}{c}2-9,12-19 \\
22-29\end{array}$ & & 2630,150 & & \\
\hline & $10,20,30$ & & $3750,000 *$ & & \\
\hline & 11,21 & & $5730,150 * \subset$ & & \\
\hline & $\ldots \ldots \ldots$ & & & & \\
\hline & $1-30$ & & & 2171,000 & 2861,000 \\
\hline \multirow[t]{5}{*}{ Annual crop yields } & $1-3$ & 9025,000 & & & \\
\hline & $4-6$ & $11,225,000 * *$ & & & \\
\hline & 7,8 & $13,125,000 * *$ & & & \\
\hline & $9-30$ & $20,025,000 * *$ & & & \\
\hline & $1-30$ & & $19,348,333$ & $15,000,000$ & $15,000,000$ \\
\hline Revenue from selling timber & $10,20,30$ & $\mathrm{n} / \mathrm{a}$ & $300,000,000 * * *$ & & \\
\hline $\operatorname{NPV}(r=10 \%)$ & & $122,077,993$ & $330,154,427$ & $120,937,885$ & $114,433,314$ \\
\hline $\mathrm{B} / \mathrm{C}$ & & 10.36 & 16.19 & 6.91 & 5.24 \\
\hline Payback period (year) & & 1 & 1 & 1 & 1 \\
\hline
\end{tabular}

Agroforestry 1 (durian and cassava) = no cost for cassava seeds/seedlings from years $2-30$ as farmers produce it from the previous year; additional labor cost* for the durian harvesting** in the years 4-6 (trees first bearing fruit/low production), 7-8 (medium production) and 9-30 (full production)

Agroforestry 2 (teak, yam, maize) = additional labor cost $*$ for timber harvesting*** in years 10, 20, 30, and land preparation (e.g. stump clearing) in years 11,21 ; extra cost for seedlings $($ in years 11,21

Cost and revenue are estimated to be the same for years 1-30 for swidden 1 (upland rice) and swidden 2 (maize)

Through the semi-structured questionnaire interviews and FGDs, it was identified that agroforestry not only creates production capacity, but also tree planting establishes more permanent land rights for farmers, with those rights transferring to future generations. In contrast, fallow or swidden systems may weaken tenure security. One of the respondents established his durian-based agroforestry farm in 2001, and he remembered that before practicing agroforestry 'I left my land abandoned and one of my neighbors used it to stack his logs to sell that he had harvested'. During FGDs, it was reported that cultivation categories defined as 'agroforestry' are prestigious in the community, owing to the high value of tree products (e.g. teak, durian) which have higher monetary value than do products from swidden agriculture. Additionally, agroforestry farmers share their fruit and vegetable products with neighbors, providing direct benefits to others and strengthening social cohesion. Agroforestry also creates various jobs, such as traders and regular or seasonal wage-laborers for harvesting, transporting, sorting etc. of fruit and timber, thus supporting the emergence of farm-related rural employment and specialization.

Despite agroforestry systems being more profitable, more prestigious and better for securing land use rights, some farmers in the study area still persist with the less profitable swidden cultivation. The semistructured questionnaire interviews with 20 key informant swidden farmers revealed some of the 
Table 3 Sensitivity of profitability (NPV) to change in discount rate of agroforestry and swidden cultivation systems

\begin{tabular}{lrrrr}
\hline Discount rate (r) $(\%)$ & \multicolumn{4}{l}{ NPV } \\
\cline { 2 - 5 } & Agroforestry 1 & Agroforestry 2 & \multicolumn{1}{l}{ Swidden 1 } & \multicolumn{1}{c}{ Swidden 2 } \\
\hline 5 & $221,438,725$ & $616,502,476$ & $197,213,174$ & $186,606,183$ \\
10 & $122,077,993$ & $330,154,427$ & $120,937,885$ & $114,433,314$ \\
20 & $53,588,283$ & $137,580,080$ & $63,874,775$ & $60,439,308$ \\
30 & $31,582,414$ & $76,579,723$ & $42,747,011$ & $40,447,889$ \\
40 & $21,803,255$ & $50,274,014$ & $32,071,174$ & $30,346,246$ \\
50 & $16,499,245$ & $36,674,210$ & $25,657,866$ & $24,277,873$ \\
60 & $13,228,225$ & $28,714,082$ & $21,381,650$ & $20,231,651$ \\
70 & $11,026,191$ & $23,599,254$ & $18,327,140$ & $17,341,426$ \\
80 & 9447,968 & $20,065,665$ & $16,036,249$ & $15,173,749$ \\
90 & 8263,065 & $17,482,427$ & $14,254,444$ & $13,487,777$ \\
\hline
\end{tabular}

Table 4 Sensitivity of profitability (NPV) to varying the yields of agroforestry and swidden cultivation systems

\begin{tabular}{lrrrr}
\hline Decrease of production $(\%)$ & \multicolumn{4}{l}{ NPV $(\mathrm{r}=10 \%)$} \\
\cline { 2 - 5 } & Agroforestry 1 & Agroforestry 2 & Swidden 1 & Swidden 2 \\
\hline 0 & $122,077,993$ & $330,154,427$ & $120,937,885$ & $114,433,314$ \\
5 & $115,974,093$ & $313,646,706$ & $114,890,991$ & $108,711,648$ \\
10 & $109,870,193$ & $297,138,984$ & $108,844,097$ & $102,989,983$ \\
20 & $97,662,394$ & $264,123,542$ & $96,750,308$ & $91,546,651$ \\
30 & $85,454,595$ & $231,108,099$ & $84,656,519$ & $80,103,320$ \\
40 & $73,246,795$ & $198,092,656$ & $72,562,731$ & $68,659,988$ \\
50 & $61,038,996$ & $165,077,213$ & $60,468,942$ & $57,216,657$ \\
60 & $48,831,197$ & $132,061,771$ & $48,375,154$ & $45,773,325$ \\
70 & $36,623,397$ & $99,046,328$ & $36,281,365$ & $34,329,994$ \\
80 & $24,415,598$ & $66,030,885$ & $24,187,577$ & $22,886,662$ \\
90 & $12,207,799$ & $33,015,442$ & $12,093,788$ & $11,443,331$ \\
\hline
\end{tabular}

Table 5 Constraints on the adoption of agroforestry, as mentioned by 20 swidden farmers. The motivational factor is marked with $\mathrm{M}$ and factors related to capacity are marked with C

\begin{tabular}{lll}
\hline Reasons & $\begin{array}{l}\text { Number of } \\
\text { farmers }\end{array}$ & $\begin{array}{l}\text { Per } \\
\text { cent }\end{array}$ \\
\hline (1) No interest (M) & 18 & 90 \\
(2) Lack of sufficient knowledge & 7 & 35 \\
(C) & 16 & \\
(3) Lack of capital (C) & 4 & 20 \\
(4) Lack of technical assistance & & \\
(C) & & \\
\hline
\end{tabular}

factors underlying non-adoption of agroforestry (Table 5). Adoption is hampered by capacity $(2,3$, 4) and motivational (1) factors. Capacity constraints were mentioned 27 times by the farmers, while motivational factors were mentioned 18 times. 'No interest' in agroforestry practice is deeply rooted in their tradition, whereas swidden practice has been practiced by generations. 'Lack of capital' is also a serious constraint on initial investment in agroforestry. This is particularly true for swidden farmers as their cultivation practices are largely subsistence-oriented and yield insufficient capital to invest in agroforestry, i.e. it requires about half of their annual household income to invest in agroforestry (Tables 2 and 6). Lack of technical assistance is another major constraint as government programs to promote agroforestry do not exist in the study site. There is no agroforestry extension, no technical or market information, no price guarantees and no supply of high quality seedlings. 
Table 6 Farm size, income, forest clearing activity and collecting of forest products by swidden farmers and agroforestry farmers

\begin{tabular}{|c|c|c|}
\hline Description & Swidden farmers $(n=20)$ & $\begin{array}{l}\text { Agroforestry farmers } \\
(\mathrm{n}=20)\end{array}$ \\
\hline Total swidden land (ha) & 0.46 & - \\
\hline Total agroforestry land (ha) & - & 0.85 \\
\hline Total other cropland (ha) & 0.29 & 0.11 \\
\hline Total homestead land (ha) & 0.02 & 0.02 \\
\hline Total land area (ha) & 0.77 & 0.98 \\
\hline Total annual income from all sources (million IDR) & 12.07 & 20.15 \\
\hline $\begin{array}{l}\text { Total annual income from swidden/agroforestry (million } \\
\text { IDR) }\end{array}$ & 1.04 & 3.25 \\
\hline Total annual income from other cropland (million IDR) & 2.52 & 1.66 \\
\hline Forest area cleared per household (last 5 years) (ha) & 0.29 & 0.09 \\
\hline Reason for clearing & $\begin{array}{l}\text { Swidden: } 45 \% \text { Permanent monoculture: } \\
35 \% \\
\text { Plantation: } 0.5 \% \\
\text { Not cleared: } 15 \%\end{array}$ & $\begin{array}{l}\text { Agroforestry: } 15 \% \\
\text { Permanent monoculture: } \\
15 \% \\
\text { Not cleared: } 70 \%\end{array}$ \\
\hline $\begin{array}{l}\text { Distance to the edge of nearest forest (minutes of } \\
\text { walking) }\end{array}$ & 24.0 & 10.6 \\
\hline $\begin{array}{l}\text { Firewood collected from forest per household } \\
\left(\mathrm{kg} \mathrm{month}^{-1}\right)\end{array}$ & 33 & 5.60 \\
\hline Fodder collected from forest per household $\left(\mathrm{kg} \mathrm{month}{ }^{-1}\right)$ & 1.65 & 3.15 \\
\hline Forest food ${ }^{\mathbf{a}}$ collected per household $\left(\mathrm{kg} \mathrm{month}^{-1}\right)$ & 4.85 & 1.70 \\
\hline
\end{tabular}

a Forest food mainly constitutes bamboo shoots, mushrooms, tubers and other leafy vegetables, nuts and fruit including rambutan, menteng and wild bananas

The interviews with the 40 key informant farmers revealed that most of the swidden lands in the study site are semi-permanent with cultivation interspersed with either short or long fallow periods, whereas other agricultural land is cultivated continuously without fallow periods. Swidden farmers occupy less land than agroforestry farmers because (i) low household income restricts them from investing in new land and (ii) limited labor is available for agriculture as a high proportion of household labor is required for off-farm work which accounts for a high proportion of their income $^{10}$ (Table 6). Eight-five per cent of swidden farmers were involved in forest clearing whereas only $30 \%$ of agroforestry farmers were involved in this activity. As a result, on average a swidden farming household cleared a larger area (0.29 ha) of forest than

\footnotetext{
${ }^{10}$ Annual household off-farm income is calculated to be 8.5 and 15.2 million IDR, i.e. 70 and $75 \%$ of total household income for swidden and agroforestry farmers respectively, and much greater than the total farm income. During FGDs it was reported that households allocate a high proportion of their labor to this off-farm work.
}

an agroforestry farming household (0.09 ha). Among swidden farmers, $45 \%$ of them cleared forest for the establishment (by slash-and-burn) of swidden farming, whereas a relatively low number of agroforestry farmers $(15 \%)$ cleared forest for agroforestry purposes.

Swidden farmers collect, on average, more firewood from forests than do agroforestry farmers (Table 6). In interviews, the respondents said that this difference is because there is a big stock of firewood available in the agroforestry farms, especially from tree pruning and thinning. Also, their relatively higher farm income enables agroforestry farmers to buy gas cylinders, thereby reducing their need for firewood. Cattle rearing is not common in the research site, thus the rate of fodder collection from forest is low. Swidden farmers collect more forest food than agroforestry farmers. This was due to the diversity of crop species in agroforestry systems providing various types of food, and at the same time the higher farm income of agroforestry farmers enabled their households to buy food from local markets. There are a total of 4 timber, 15 fruit and nut, and 23 other understory crop species cultivated in the agroforestry systems. 


\section{Discussion}

As an alternative to swidden farming, in the Gunung Salak study site agroforestry systems were found to be financially profitable and have good potential to secure sustainable livelihoods through diversified food sources and strengthened land tenure. Durian- and teak-based agroforestry systems are the most popular in the study site. The $\mathrm{B} / \mathrm{C}$ indicated that total monetary gain is much higher in both of these systems than the total costs required to undertake the project, and much higher than for swidden systems. In addition, the payback period showed that there was no notable problem of delayed cash returns for those farmers adopting either agroforestry system; it was equal to the 1 year period of the swidden systems. However, NPV showed only one agroforestry system (the teak-based one) to be notably more profitable than both the swidden systems. Both sensitivity analyses confirmed that it is the teak-based agroforestry system that is more profitable over a range of conditions than are the durian-based agroforestry or swidden cultivation systems.

Smallholder teak production in Java is an important source of cash income for rural families (Roshetko et al. 2013) and has become part of many farmers' culture (Perdana et al. 2012), whereas swidden has retained this cultural status in the study area. There are 1.5 million smallholder farmers in Java managing 444,000 ha of tree-based agroforestry systems, where teak is the dominant tree crop. In other parts of Indonesia, there is an additional 800,000 ha of smallholder agroforestry, where teak is one component of multispecies, tree-based systems, favored because of its high market price (Departemen Kehutanan 2005). In Central and East Java, smallholder farmers see tree farming systems as a 'living savings account' that diversifies production, reduces risk, and builds assets to enhance family incomes and security (van Noordwijk et al. 2008). De Foresta et al. (2004) found that the average annual income from mature fruit and timber agroforestry systems in Krui, Lampung were IDR 2,410,000 $\mathrm{ha}^{-1} \mathrm{yr}^{-1}$. Tree farming systems in the Philippines provided a range of annual incomes equivalent to IDR 2,374,802$163,553,043 \mathrm{ha}^{-1} \mathrm{yr}^{-1}$, which greatly exceed incomes provided by annual crop systems, and the imperata grassland shifting cultivation system (Predo 2002). Tree-based production systems are also promoted in government policies because of their perceived biological, economic and social resilience in the context of anthropogenic climate change and other production challenges (Alfaro et al. 2014; Steffan-Dewenter et al. 2007; Thorlakson and Neufeldt 2012).

In our research site, through active tree planting, agroforestry creates permanent rights to farm land that transfer to future generations. Practicing this permanent form of cultivation is also prestigious in the community, because the tree products have high monetary and social values. From a social and institutional point of view, agroforestry is an important element in smallholder farmers' land security strategies in Indonesia (Michon and de Foresta, 1999), giving farmers the opportunity to secure tenure, as the recognized tree planter, with the property being legally transferred to descendants as patrimony (Michon 2005).

Furthermore, swidden farmers have capacity constraints on agricultural cultivation of a large land area, thus they are only able to use less land than agroforestry farmers. Low household income limits the capacity to invest in cultivating new land, due to the importance of off-farm income in the livelihoods of the studied households. Available labor to cultivate agricultural crops is the most limiting resource for them. On the other hand, more permanent sustainable agroforestry practices require less labor input. Thus, smallholder tree cultivation is recognized as a viable livelihood strategy in various agroforestry and community forestry programs (e.g. FAO 2006; Sales et al. 2005; ICRAF 2003).

The debates on the underlying causes of tropical deforestation and the drivers of agents' behaviour are complex, and the relationships between forest clearing and household and contextual variables vary depending on the setting (VanWey et al. 2005). Even with a limited land holding capacity, swidden farming households at our study site cleared a larger area of forest than did agroforestry farming households. Even though the average distance of swidden farm household to the nearest forest is relatively far, they collected more firewood from forests than did agroforestry households. This is because agroforestry farms have a good supply of firewood, and relatively higher farm income allowing a larger proportion of agroforestry farmers to buy gas cylinders. Recent studies in different locations around the tropics 
indicate that one important reason for deforestation is crop growing (Babigumira et al. 2014), and swidden farming is often held to be the principle driving force for that (Fox et al. 2000; Angelsen 1995; Myers 1992). However, Heltberg et al. (2000) reported that one of the main drivers of forest degradation in rural India is unsustainable firewood collection. A study in the buffer zone of the Kerinci Seblat National Park, Indonesia highlighted the relationship between farm diversification and reliance on adjacent national park resources (Murniati and Gintings 2001). Factors associated with a higher tendency to extract forest products from protected areas were low farm income and low supply of on-farm tree-based products. A study by Garrity et al. (2002) around the Mount Kitanglad Range National Park in Mindañao, the Philippines provides support for a link between adoption of agroforestry and reduction in pressure on forest.

Even though agroforestry systems have major economic benefits for farmers, several factors constrain agroforestry adoption. The major one in the study area is lack of investment capital and the higher traditional cultural value of swidden farming, which has been practiced by many generations, within the local communities. There is an absence of government assistance which could help to overcome these barriers to adoption of agroforestry. Several other studies have also found that tradition and customs are still a decisive factor influencing farmers' choice to practice swidden cultivation (Padoch et al. 2014; Peng et al. 2014; Predo 2002) and that lack of capital and government backing ${ }^{11}$ are crucial constraints on agroforestry adoption (Rahman et al. 2012; Van et al. 2012; Mai 1999). Institutional innovation theory pioneered by economists (Hayami and Ruttan 1971; Schultz 1964) argues that physical constraints can be compensated by knowledge and institutional influence. Empirical evidence from Sumatra, Indonesia illustrated that with a supportive local institutional influence, tree culture has extended greatly into the landscape of swidden cultivation fields where young trees are cultivated with crops (Michon 2005). Swidden cultivation eventually disappeared when the

\footnotetext{
$\overline{11}$ Other studies conducted in West Java, Sumatra, and Sulawesi also indicate that technical assistance is an important factor for agroforestry farm intensification and farmer motivation (Martini et al. 2012; Manurung et al. 2008; Roshetko et al. 2007).
}

agroforestry silvicultural system had sufficiently matured and started to function as a productive and profitable tree-based system. When agroforestry systems fit local biophysical and socioeconomic conditions, they can rapidly become part of local culture (Perdana et al. 2012). There is potential for this intensification to be achieved in our study area through a smooth adaptation of tree-based farming practices with necessary government backup, thus the association of 'agro' and 'forest' components will occur at the level of the farming system itself, and if adopted at a sufficient scale it will significantly contribute to increasing tree cover in agricultural landscapes (see also Michon 2005).

\section{Conclusions}

Communities in Gunung Salak have created a cultivated landscape which their livelihoods depend on. Their traditional swidden cultivation practices provide various subsistence products, but they can have serious negative environmental consequences by contributing to deforestation and land degradation. Agroforestry is an alternative cultivation strategy that has been adopted by some farmers within the communities. It does increase average farm income, making it more resilient to changes in market and economic conditions, and reduce pressure on adjacent forest for conversion to agriculture and as a source of firewood, fruits, vegetables and other products. These agroforestry systems also enable farmers to secure permanent land tenure and can improve social cohesive in communities. Adoption of agroforestry by farmers in the Salak valley can be increased by the implementation of supportive policies and measures (including capital support and technical assistance) by government and non-government organizations. These measures are most likely to be effective if they are sensitive to the strong local tradition of swidden cultivation and underlying systems of local knowledge. Effective policies should be propagated not by temporary projects but by permanent, government-backed institutions that are focused on agroforestry practices and the needs for their adaptation to meet new opportunities and constraints (see also Rahman et al. 2008). The successful adoption of durian-and teak-based agroforestry by many farmers in the study area indicates the high potential for success of such a programme. 
Acknowledgments This work is funded by Forest and Nature for Society (FONASO, initiated by the Erasmus Mundus programme of the European Commission to enhance and promote European higher education throughout the world) and Center for International Forestry Research (CIFOR). The authors are grateful to the scientists and staff of Bangor University, University of Copenhagen, CIFOR and ICRAF who provided support and guidance. Many thanks are also extended to the people at the study sites where the field investigation was undertaken, who shared their precious time, knowledge and concerns.

Open Access This article is distributed under the terms of the Creative Commons Attribution 4.0 International License (http:// creativecommons.org/licenses/by/4.0/), which permits unrestricted use, distribution, and reproduction in any medium, provided you give appropriate credit to the original author(s) and the source, provide a link to the Creative Commons license, and indicate if changes were made.

\section{References}

Adimihardja K (1992) Kasepuhan yang Tumbuh di Atas yang Luruh: Pengelolaan Lingkungan secara Tradisional di Kawasan Gunung Halimun Jawa Barat. Tarsito, Bandung

Ahmed MFU, Rahman SML (2000) Agroforestry farming system in the homesteads of Gazipur, Central Bangladesh. Texas A \& M University, Dallas

Alfaro R, Fady B, Vendramin GG, Dawson IK, Fleming RA, Saenz-Romero C, Lindig-Cisneros RA, Murdock T, Vinceti B, Navarro CM (2014) The role of forest genetic resources in responding to biotic and abiotic factors in the context of anthropogenic climate change. For Ecol Manag 333:76-87

Angelsen A (1995) Shifting cultivation and deforestation: a study from Indonesia. World Dev 23(10):1713-1729

Angelsen A, Larsen HO, Lund JF, Smith-Hall C, Wunder S (eds) (2011) Measuring livelihoods and environmental dependence: methods for research and fieldwork. CIFOR, Bogor

Aweto AO (2013) Shifting cultivation and secondary succession in the tropics. CABI, Oxfordshire

Babigumira R, Angelsen A, Buis M, Bauch S, Sunderland T, Wunder S (2014) Forest clearing in rural livelihoods: household-level global-comparative evidence. World Dev 64:67-79

Badan Pusat Statistik (2013) Statistik Daerah Kabupaten Bogor Tahun 2013. Komplek Perkantoran Pemkab Bogor, Bogor

Barraclough SL, Ghimire KB (1995) Forests and Livelihoods: the Social dynamics of deforestation in developing countries. International Political Series. UNRISD, London

Coulter JK (1972) Soil management systems. National Academy of Sciences, Washington D.C.

Craswell ET, Sajjapongse A, Howlett DJB, Dowling AJ (1998) Agroforestry in the management of sloping lands in Asia and the Pacific. Agrofor Syst 38:121-137

Dahlquist RM, Whelan MP, Winowiecki L, Polidoro B, Candela S, Harvey CA, Wulfhorst JD, McDabiel PA, Bosque-Perez NA (2007) Incorporating livelihoods in biodiversity conservation: a case study of cacao agroforestry systems in
Talamanca, Costa Rica. Biodivers Conserv 16(8):23112333

DANIDA (Danish International Development Agency) (2000). Identification report. Watershed development project, Chittagong Hill Tracts, Bangladesh

de Foresta H, Michon G, Kusworo A, Levang P (2004) Damar agroforest in Sumatra, Indonesia: domestication of forest ecosystem through domestication of Dipterocarps for resin production. In: Kusters K, Belchers B (eds) Forest products, livelihoods and conservation, case studies of nontimber forest product systems, vol 1. CIFOR, Bogor, pp 202-221

Departemen Kehutanan (2005) Data Potensi Hutan Rakyat. Direktorat Jenderal Rehabilitasi Lahan dan Perhutanan Sosial dan Biro Pusat Statistik. Ministry of Forestry, Jakarta

Disney SM, Warburton RDH, Zhong CQ (2013) Net present value analysis of the economic production quantity. J Manag Math 24:423-435

Elevitch C, Wilkinson KM (1998) A guide to orchard alley cropping for fertility, mulch and soil conservation. AgroForester, Hawaii

Elevitch CR, Wilkinson KM (2000) Economics of farm forestry: financial evaluation for landowners. agroforestry guides for Pacific Islands \# 7. Permanent Agricultural Resources (PAR), Hawaii

EST (Endangered Species Team) (2015) Ecological study Halimun-Salak corridor Mount Halimun-Salak national park, GHSNPMP-JICA. http://www.sci.kagoshima-u.ac. $\mathrm{jp} /$ itp/student/siryo/Corridor\%20Study-Eng2005.pdf. Accessed 10 Apr 2015

FAO (2000). Forest Resource Assessment 2000: on definitions of forest and forest change. Working Paper 33. FAO, Rome

FAO (2006) Better forestry, less poverty: a practitioner's guide. FAO, Rome

FAO (2015) What is rapid rural appraisal?. http://www.fao.org/ docrep/006/W2352E/W2352E03.htm. Accessed 9 Jan 2015

Fisher L, Bunch R (1996) Challenges in promoting forest patches in rural development efforts. In: Schelhas J, Greenberg R (eds) Forest patches in tropical landscapes. Island Pressure, Washington D.C., pp 381-400

Fox J, Truong DM, Rambo AT, Tuyen NP, Cuc LT, Leisz AS (2000) Shifting cultivation: a new old paradigm for managing tropical forests. Bioscience 50(6):521-528

Franzel S, Scherr SJ (2002) Introduction. In: Franzel S, Scherr SJ (eds) Trees on the farm: assessing the adoption potential of agroforestry practices in Africa. CABI, Wallingford, pp 1-11

Galudra G, Nurhawan R, Aprianto A., Sunarya Y, Engkus, (2008) The last remnants of mega biodiversity in West Java and Banten: an in-depth exploration of RaTA (Rapid Land Tenure Assessment) in Mount Halimun-Salak National Park, Indonesia, Working Paper no. 69. World Agroforestry Centre, Bogor

Garrity DP (2004) Agroforestry and the achievement of the millennium development goals. Agrofor Syst 61:5-17

Garrity D, Amoroso VB, Koffa S, Catacu-tan D, Buenavista G, Fay P, Dar W (2002) Landcare on the poverty-protection interface in an Asian watershed. Conserv Ecol 6(1):12

Gupta A (1993) Ecology and Development in the Third World. Routledge, London 
Hayami Y, Ruttan VW (1971) Agricultural development: an international perspective. The Johns Hopkins University Press, USA

Heltberg R, Arndt TC, Sekhar NU (2000) Fuelwood consumption and forest degradation: a household model for domestic energy substitution in rural India. Land Econ $76(2): 213-232$

Huxley PA (1993) Tree crop interface orientation experiment with Grevillea robusta hedgerows and maize. Agrofor Syst 26:23-45

ICRAF (2003) Agroforestry for poverty reduction: realizing the potential. Strategic plan for ICRAF East and Central Africa Program 2000-2010. ICRAF, Nairobi

Idol T, Haggar J, Cox L (2011) Ecosystem services from smallholder forestry and agroforestry in the tropics. In: Campbell WB, Ortiz SL (eds) Integrating agriculture, conservation and ecotourism: examples from the field, issues in agroecology-present status and future prospectus, vol 1. Springer, New York, pp 209-270

Imang N, Inoue M, Sardjono MA (2008) Tradition and the influence of monetary economy in swidden agriculture among the Kenyah people of East Kalimantan, Indonesia. Int J Soc For (IJSF) 1(1):61-82

Inoue M (2000) Mechanism of changes in the Kenyah's swidden system: explanation in terms of zensification theory. In: Guhardja E, Fatawi M, Sutisna M, Mori T, Ohta S (eds) Rainforest Ecosystems of East Kalimantan-El Niño, drought, fire and human impacts. Springer-Verlag, Tokyo, pp $167-184$

Jepma CJ (2013) Tropical Deforestation: a socio-economic approach. Routledge, New York

Jessica LB, Stewart AWD, James PG, Stephen VS, Jorge MV (2014) Implications of Mayan agroforestry for biodiversity conservation in the Calakmul biosphere reserve, Mexico. Agrofor Syst 88:269-285

Kiptot E, Hebinck P, Franzel S, Richards P (2007) Adopters, testers or pseudo-adopters? dynamics of the use of improved tree fallows by farmers in Western Kenya. Agric Syst 94(2):509-519

Kleden OE, Chidley L, Indradi Y (eds.) (2009) Forests for the future: indigenous forest management in a changing world. Indigenous peoples alliance of the Archipelago, and down to earth, Jakarta

Leakey RRB (2010) Agroforestry: a delivery mechanism for multi-functional agriculture. In: Kellimore LR (ed) Handbook on agroforestry: management practices and environmental impact, environmental science, engineering and technology series. Nova Science Publishers, Hauppauge, pp 461-471

Leakey RRB, Weber JC, Page T, Cornelius JP, Akinnifesi FK, Roshetko JM, Tchoundjeu Z, Jamnadass R (2012) Tree domestication in agroforestry: progress in the second decade (2003-2012). In: Nair PKR, Garrity D (eds) Agroforestry: the future of global land use, advances in agroforestry series, vol 9. Springer, Dordrecht, pp 145-173

Macdicken KG, Vergara NT (1990) Agroforestry: classification and management. Wiley, New York

Mai PT (1999) Socio-economic analysis of shifting cultivation versus agroforestry system in the upper stream of lower Mekong watershed in Dak Lak province. MA Thesis in economics of development. College of Economics,
National University-HCMC, Viet Nam, and Institute of Social Study (ISS), The Netherlands

Manurung GES, Roshetko JM, Budidarsono S, Kurniawan I (2008) Dudukuhan tree farming systems in West Java: how to mobilize self-strengthening of community-based forest management? In: Snelder DJ, Lasco RD (eds) Smallholder tree growing for rural development and environmental services: lessons from Asia. Advances in agroforestry series, vol 5. Springer, Dordrecht, pp 99-116

Marten GG (1986) Traditional agriculture in Southeast Asia: a human ecology perspective. Westview Press, Boulder

Martini E, Tarigan J, Purnomosidhi P, Prahmono A, Surgana M, Setiawan A, Megawati, Mulyoutami E, Meldy BD, Syamsidar, Talui R, Janudianto, Suyanto S, Roshetko JM (2012) Agroforestry and forestry in Sulawesi series: agroforestry extension needs at the community level in AgFor project sites in South and Southeast Sulawesi, Indonesia. Working paper 159. ICRAF, Bogor

Mead D.J (2004) Agroforestry. Encyclopedia of life support systems. Vol. 1, pp 324-355

Meijer SS, Catacutan D, Ajayi OC, Sileshi GW, Nieuwenhuis M (2015) The role of knowledge, attitudes and perceptions in the uptake of agricultural and agroforestry innovations among smallholder farmers in sub-Saharan Africa. Int $\mathbf{J}$ Agric Sustain 13(1):40-54

Mertz O, Padoch C, Fox J, Cramb R, Leisz S, Lam N, Vien T (2009) Swidden change in Southeast Asia: understanding causes and consequences. Hum Ecol 37:259-264

Michon G (ed) (2005) Domesticating forests: how farmers manage forest resources. IRD, CIFOR and ICRAF, Nairobi

Michon G, de Foresta H (1999) Agro-forests: incorporating a forest vision in agroforestry. In: Buck LE, Lassoie JP, Fernandes ECM (eds) Agroforestry in sustainable agricultural systems. Lewis Publishers, New York, pp 318-406

Munthali KG (2013) Modelling deforestation in dzalanyama forest reserve, Lilongwe, Malawi: using multi-agent simulation approach. Ph.D. Dissertation, University of Tsukuba, Tsukuba

Murniati Garrity DP, Gintings AN (2001) The contribution of agroforestry systems to reducing farmers' dependence on the resources of adjacent national parks: a case study from Sumatra. Agrofor Syst 52:171-184

Myers N (1992) Tropical forests: the policy challenge. Environmentalist 12(1):15-27

Nair PKR, Dagar JC (1991) An approach to developing methodologies for evaluating agroforestry systems in India. Agrofor Syst 16:55-81

Padoch C, Coffey K, Mertz O, Leisz SJ, Fox J, Wadley RL (2014) The demise of swidden in southeast Asia? local realities and regional ambiguities. Dan J Geogr 107(1):29-41

Peng L, Zhiming F, Luguang J, Chenhua L, Jinghua Z (2014) A review of swidden agriculture in Southeast Asia. Remote Sens 6:1654-1683

Perdana A, Roshetko JM, Kurniawan I (2012) Forces of competition: smallholding teak producers in Indonesia. Int For Rev 14(2):238-248

Predo CD (2002) Bioeconomic analysis of land use options for grassland areas in Claveria, Misamis Oriental. Leyte State University, Leyte

Rahman SA, Groot W, Snelder DJ (2008) Exploring the agroforestry adoption gap: financial and socioeconomics of 
litchi-based agroforestry by smallholders in Rajshahi (Bangladesh). In: Snelder DJ, Lasco RD (eds) Smallholder tree growing for rural development and environmental services: lessons from Asia. Advances in agroforestry series, vol 5. Springer, Dordrecht, pp 227-244

Rahman SA, Rahman MF, Sunderland T (2012) Causes and consequences of shifting cultivation and its alternative in the hill tracts of eastern Bangladesh. Agrofor Syst 84(2):141-155

Rahman SA, Rahman MF, Sunderland T (2014) Increasing tree cover in degrading landscapes: 'integration' and 'intensification' of smallholder forest culture in the alutilla valley, Matiranga, Bangladesh. Small-scale For 13:237-249

Roshetko JM, Martini E, Tarigan J, Manurung G, Budidarsono S, Wijaya K, Tukan JC, Kurniawan I, Galudra G, Nugroho DK, Ekadinata A, SDewi S, Lusiana DHB, van Noordwijk M, Purba J (2007) Agroforestry on the interface of orangutan conservation and sustainable livelihoods in Batang Toru (North Sumatra). Working Paper no. 56. ICRAF, Bogor

Roshetko JM, Snelder SD, Lasco RD, van Noordwijk M (2008) Future challenge: a paradigm shift in the forestry sector. In: Snelder DJ, Lasco RD (eds) Smallholder tree growing for rural development and environmental services: lessons from Asia. Advances in agroforestry series, vol 5. Springer, Dordrecht, pp 453-485

Roshetko JM, Rohadi D, Perdana A, Sabastian G, Nuryartono N, Pramono AA, Widyani N, Manalu P, Fauzi MA, Sumardamto P, Kusumowardhani N (2013) Teak agroforestry systems for livelihood enhancement, industrial timber production, and environmental rehabilitation. For Trees Livelihoods 22(4):251-256

Russell W (1988) Population, swidden farming and the tropical environment. Popul Environ 10:77-94

Sae-Lee S, Vityakon P, Prachaiyo B (1992) Effects of trees on paddy bund on soil fertility and rice growth in northeast Thailand. Agrofor Syst 18:213-223

Sales RF, Lasco RD, Bonaticla R (2005) Carbon storage and sequestration potential of smallholder tree farms on Leyte Island, The Philippins. In: Harrison S, Herbohn J, Mangaoan E, Vanclay J (eds.) ACIAR smallholder forestry project ASEM 200/008, redevelopment of a timber industry following extensive land clearing. Proceedings from the end of Project Workshop, 19-21 August 2004, Ormoc City

Saxena NC, Ballabh V (1995) Farm forestry and the context of farming systems in South Asia. In: Saxena NC, Ballabh V (eds) Farm forestry in South Asia. Sage Publications, New Delhi, pp 23-50

Schuck EC, Nganje W, Yantio D (2002) The role of land tenure and extension education in the adoption of slash and burn agriculture. Ecol Econ 43:61-70

Schultz TW (1964) Transforming traditional agriculture. Yale University Press, USA

Sfeir-Younis A, Dragun AK (1993) Land and soil management: technology, economics and institutions. West View Press, Boulder

Shoaib JU, Mostafa G, Rahman M (1998) Soil erosion hazard in Chittagong Hill tracts: a case study. Annual report. Soil Resources Development Institute, Dhaka
Steffan-Dewenter I, Kessler M, Barkmann J, Bos MM, Buchori D, Erasmi S, Faust H, Gerold G, Glenk K, Gradstein SR, Guhardja E, Harteveld M, Hertel D, Höhn P, Kappas M, Köhler S, Leuschner C, Maertens M, Marggraf R, MiggeKleian S, Mogea J, Pitopang R, Schaefer M, Schwarze S, Sporn SG, Steingrebe A, Tjitrosoedirdjo SS, Tjitrosoemito S, Twele A, Weber R, Woltmann L, Zeller M, Tscharntke T (2007) Tradeoffs between income, biodiversity, and ecosystem functioning during tropical rainforest conversion and agroforestry intensification. Proc Natl Acad Sci USA 104(12):4973-4978

Stocking M, Bojo J, Abel N (1990) Financial and economic analysis of agroforestry: key issues. In: Prinsley RT (ed) Agroforestry for sustainable production: economic implications. The Commonwealth Secretariat, London, pp 13-119

Styger E, Rakotondramasy HM, Pfeffer MJ, Fernandes ECM, Bates DM (2007) Influence of slash-and-burn farming practices on fallow succession and land degradation in the rainforest region of Madagascar. Agric Ecosyst Environ 119:257-269

Sunderland TCH, Clark LE, Vantomme P (eds) (1999) The nonwood forest products of Central Africa: current research issues and prospects for conservation and development. FAO, Rome

Swallow B, Boffa JM, Scherr SJ (2006) The potential for agroforestry to contribute to the conservation and enhancement of landscape biodiversity. In: Garrity DP, Okono A, Grayson M, Parrott S (eds) World agroforestry into the future. World Agroforestry Centre (ICRAF), Nairobi, pp 95-101

Therik T (1999) The role of fire in swidden cultivation: a timor case study. In: Russell SJ, Hill GJE, Djoeroemana S, Myers BA (eds) Fire and sustainable agricultural and forestry development in Indonesia and northern Australia. Australian Centre for International Agricultural Research (ACIAR), Canberra, pp 77-79

Thorlakson T, Neufeldt H (2012) Reducing subsistence farmers' vulnerability to climate change: evaluating the potential contributions of agroforestry in Western Kenya. Agric Food Secur 1:1-15

van Noordwijk M, Roshetko JM, Angeles MD, Suyanto Fay C, Tomich TP (2008) Farmer tree planting barriers to sustainable forest management. In: Snelder DJ, Lasco RD (eds) Smallholder tree growing for rural development and environmental services: lessons from Asia. Advances in agroforestry series, vol 5. Springer, Dordrecht, pp 429-451

Van VN, Mertz O, Heinimann A, Langanke T, Pascual U, Schmook B, Adams C, Schmidt-Vogt D, Messerli P, Leisz $S$ (2012) Trends, drivers and impacts of changes in swidden cultivation in tropical forest-agriculture frontiers: a global assessment. Glob Environ Change 22:418-429

VanWey LK, Ostrom E, Meretsky V (2005) Theories underlying the study of human environment interactions. In: Moran E, Ostrom E (eds) Seeing the forest and the trees: human-environment interactions in forest ecosystems. MIT Press, Cambridge

Vongvisouk T, Mertz O, Thongmanivong S, Heinimann A, Phanvilay K (2014) Shifting cultivation stability and change: contrasting pathways of land use and livelihood change in Laos. Appl Geogr 46:1-10 
Wiharto M, Kusmana C, Prasetyo LB, Partomihardjo T (2008)

Tree diameter class distribution in various vegetation types on mount Salak, Bogor, west Java. J Ilmu Pertan Indones 13(2):95-102
Wu Y (1996) Paulownia agroforestry in China: a contribution to adaptive research. PhD Thesis. Cranfield University, Silsoe 